\title{
Effects of environmental conditions associated to the cardinal orientation on the reproductive phenology of the cerrado savanna tree Xylopia aromatica (Annonaceae)
}

\author{
MARIA GABRIEla G. CAMARgo, REgina M. SOUZA, PAUlA REYS \\ and LEONOR P.C. MORELLATO \\ Universidade Estadual Paulista/UNESP, Instituto de Biociências, Departamento de Botânica, \\ Laboratório de Fenologia, Avenida 24A, 1515, Bela Vista, 13506-900 Rio Claro, SP, Brasil \\ Manuscript received on February 8, 2010; accepted for publication on September 15, 2010
}

\begin{abstract}
The Brazilian cerrado has undergone an intense process of fragmentation, which leads to an increase in the number of remnants exposed to edge effects and associated changes on environmental conditions that may affect the phenology of plants. This study aimed to verify whether the reproductive phenology of Xylopia aromatica (Lam.) Mart. (Annonaceae) differs under different light conditions in a cerrado sensu stricto (a woody savanna) of southeastern Brazil. We compared the reproductive phenology of $X$. aromatica trees distributed on east and south cardinal faces of the cerrado during monthly observations, from January 2005 to December 2008. The east face had a higher light incidence, higher temperatures and canopy openness in relation to south face. X. aromatica showed seasonal reproduction at both faces of the cerrado, but the percentage of individuals, the synchrony and duration of phenophases were higher at the east face. The study demonstrated the influence of the environmental conditions associated to the cardinal orientation of the cerrado faces on the phenological pattern of X. aromatica. Similar responses may be observed for other species, ultimately affecting patterns of floral visitation and fruit production, which reinforces the importance of considering the cardinal direction in studies of edge effects and fragmentation.
\end{abstract}

Key words: cerrado savanna, edge effect, fragmentation, reproductive phenology, synchrony.

\section{INTRODUCTION}

The process of fragmentation of plant communities increases the proportion of edges, leading to changes in the microclimate such as increasing temperature and luminosity, and the impact of winds and decreasing humidity in the marginal portions of the fragment, called edge effects (Murcia 1995, Kapos et al. 1997). Changes in local light conditions can lead to shifts in plant phenological patterns, as detected in individuals on the border in relation to the forest interior (Restrepo et al. 1999, Landenberger and Ostergren 2002). However, the amount of solar radiation reaching the vegetation depends mainly on the cardinal orientation of the edge determining the

Correspondence to: Maria Gabriela Gutierrez de Camargo

E-mail: gabicamargo@yahoo.com micro environmental conditions and the intensity of edge effects to which the vegetation will be subjected (Wales 1972, Turton and Freiburger 1997).

The Brazilian cerrado has a high diversity of plant species, holding the richest flora among the world's tropical savannas (Klink and Machado 2005, Coutinho 2006, Silva et al. 2006). In recent decades, the cerrado savanna has undergone a drastic reduction, remaining about $34 \%$ of its original extension (Klink and Machado 2005, Silva et al. 2006). In São Paulo State, Southeastern Brazil, less than $1 \%$ of cerrado savanna original distribution is preserved on isolated patches of variable sizes (Kronka et al. 1998) usually surrounded by sugar cane plantations or pasture, which threatens the remaining native species (Pivello et al. 1999, Durigan et al. 2007). 
Phenology is the study of recurring biological events and their relation to abiotic and biotic factors (Morellato et al. 2000, Schwartz 2003). Climate at local and micro scales is the key driver shaping the time of plant reproduction, particularly flowering, with consequences for the ecosystem, since it affects all chains of plants and animals interaction (Marquis 1988, Fitter and Fitter 2002, Goulart et al. 2005). Consequently, plant phenology has gained importance in the context of evolutionary ecology and global change research (Fitter and Fitter 2002). Time of first flowering, duration and synchrony are among the key parameters used to describe plant phenology and its relation to climate or evolutionary factors (Augspurger 1983, Herrera 1988, Newstrom et al. 1994, Bolmgren 1998).

A number of phenological studies have addressed intraspecific variations on tropical tree phenology (e.g. Bolmgren 1998, Morellato 2004, Freitas and Bolmgren 2008). Studies considering the plant phenology of the cerrado savanna at species level are sparse (e.g. Goulart et al. 2005, Lenza and Klink 2006, Oliveira and Sigrist 2008, Vilela et al. 2008). However, the relationship between reproductive patterns and intraspecific synchrony has not been explored for cerrado savanna species, especially in the context of environmental changes (e.g. Goulart et al. 2005) and edge effects.

Therefore, in the present study we aimed to verify whether there are variations in the reproductive phenology of Xylopia aromatica (Lam.) Mart. (Annonaceae) trees under conditions of higher (east face) and lower (south face) light incidence in a cerrado stricto sensu fragment in southeastern Brazil. Apart from the relevance of understanding how environmental conditions associated to the cardinal orientation of edges affect the tree phenology, $X$. aromatica was chosen due to its wide distribution in the cerrado savannas, occurring from open areas of grasslands ("campo cerrado"), to cerrado savanna stricto sensu and "cerradão" (the dense forest-like savanna vegetation) (Durigan et al. 2004), and their abundance at the study area (P. Reys unpublished data).

We examined (i) whether the reproductive phenology of $X$. aromatica is seasonal and correlated with the climate at the study area, even under different light conditions (east and south faces) and (ii) whether there are differences in the proportion of trees reproducing, timing, duration and synchrony of flowering and fruiting between the east and south faces of cerrado. We expected a seasonal reproductive pattern on both faces due to the marked dry and wet seasons in the cerrado (Furley 1999), and a higher proportion of individuals of $X$. aromatica reproducing, higher synchrony and longer duration of phenophases on the eastern side, favored by the higher incidence of light (Landenberger and Ostergren 2002), compared to the south face.

\section{MATERIALS AND METHODS}

\section{AREA OF STUdY}

The study was conducted in an area of cerrado of about 260 ha located in Itirapina, state of São Paulo $\left(22^{\circ} 10^{\prime} 31.41^{\prime \prime} \mathrm{S} ; 47^{\circ} 52^{\prime} 26.13^{\prime \prime} \mathrm{W}\right)$ at $610 \mathrm{~m}$ altitude. The climate at Itirapina region is Cwa type according to Köeppen (1948) classification. The average climate for the region (1972 to 2002) shows a mean annual total rainfall of $1524 \mathrm{~mm}$ and mean temperature of $20.7^{\circ} \mathrm{C}$, with one warm, humid season from October to March (average of $32^{\circ} \mathrm{C}$ and $78 \%$ of annual precipitation) and one cool, dry season from April to September (average of $18^{\circ} \mathrm{C}$ and $16 \%$ of annual precipitation). During the study period (January 2005 to December 2008) the climate was similar among years (Fig. 2A) and followed the average pattern described for the region. Climatic data were obtained from the Climatological Station of the Center for Water Resources and Applied Ecology (CRHEA) of the University of São Paulo, located 4 km from the study area.

The study area was fragmented about 30 years ago and presents a rectangular form with sides facing the four cardinal points where the last fire occurred 20 years ago on the north face. The vegetation is cerrado stricto sensu (Coutinho 1978), a savanna-like vegetation with a discontinuous canopy and woody component reaching six to seven meters high and a kind of continuous herbaceous layer. In some parts the vegetation is denser, with some trees reaching up to $12 \mathrm{~m}$ high. Previous studies in the area did not find microenvironmental and structural differences between the edge and interior but they did detect significant differences between the east and south faces of this cerrado 


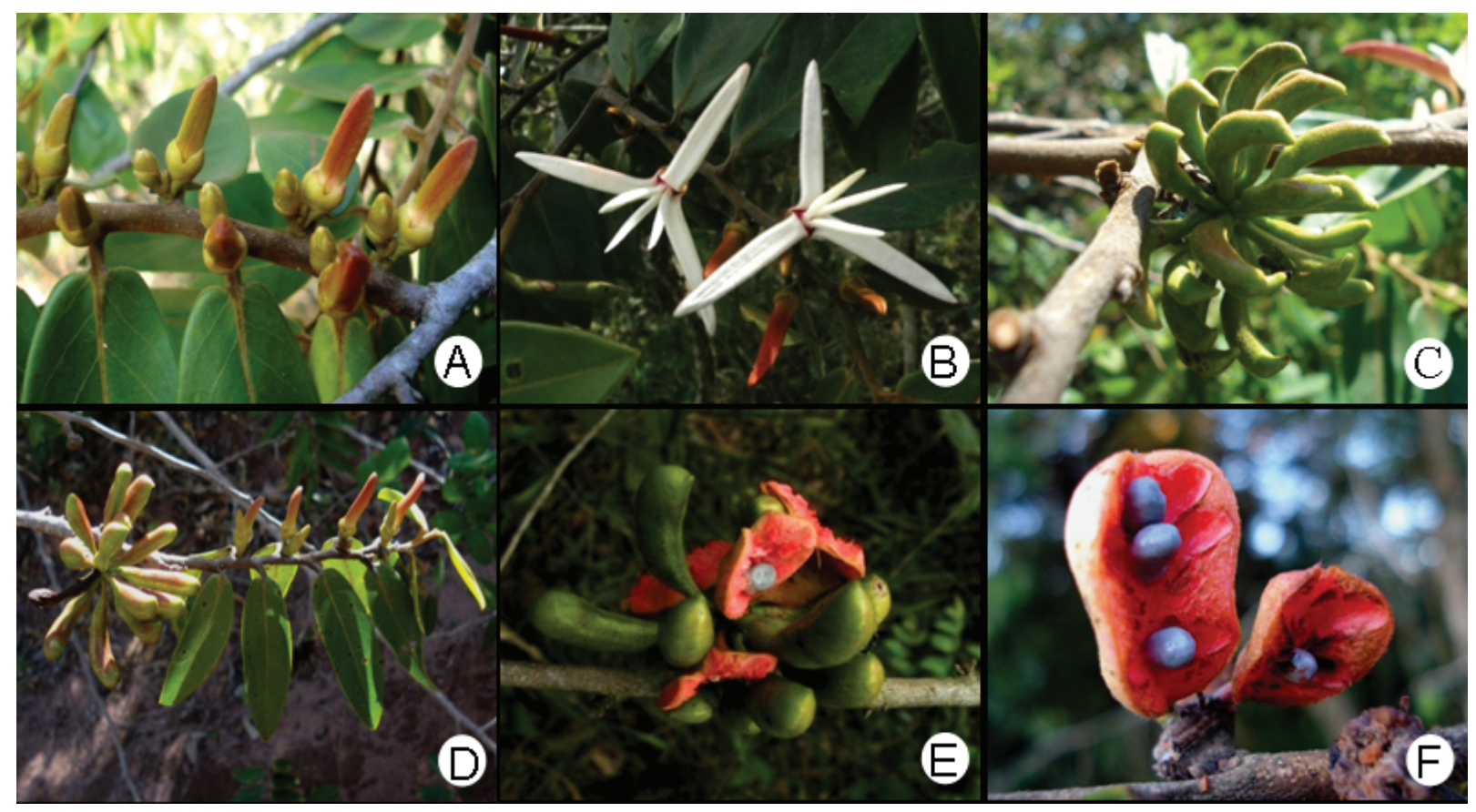

Fig. 1 - Reproductive phenology of Xylopia aromatica in a cerrado sensu stricto, Southeastern Brazil. A. flower buds; B. open flowers (anthesis); C. unripe fruits; D. ripe fruits and flower buds; E and F. ripe fruits. Photos: A, C, D and F-RMS; B and E-MGGC.

savanna (P. Reys, unpublished data). Besides the high light incidence associated with the cardinal direction, each face presents a set of different microenvironmental conditions (P. Reys, unpublished data). The east face is separated by a 5 to $8 \mathrm{~m}$ wide path from the matrix composed by another cerrado savanna and pasture, presents higher light intensity (Photosynthetic Active Radiation - PAR), temperature and canopy openness, and lower relative humidity than the south face, whose matrix was a pasture in the period of study (P. Reys, unpublished data). It is not our intention in this study to tear apart the influence of each specific microenvironmental condition related to the cardinal orientation on $X$. aromatica tree phenology.

The species Xylopia aromatica (Lam.) Mart. (Annonaceae) averages $3 \mathrm{~m}$ height and occurs in high density at the edges and interiors of both east and south faces of the cerrado studied. Trees have straight trunk, dark brown bark and pubescent twigs. Xylopia aromatica is a heliophylus species and selective xerophyte, which are reported as abundant in the open areas of the cerrado savanna and "campo cerrado" with high luminosity (Lorenzi 1992, Almeida et al. 1998). The large, white, hermaphrodite flowers occur isolated in the stems or in small groups in the leaf axils (Durigan et al. 2004) (Fig. 1A and B). The main pollinators are insects of the order Thysanoptera, genus Thrips, whereas beetles are secondary pollinators, especially the genus Cillaeus (Nitidulidae) and the family Chrysomelidae (Gottsberger and Silberbauer-Gottsberger 2006). The flesh fruits are green outside and red inside, arranged on clusters of multiple dehiscent follicles, each one with a long stalk with multiple seeds. The fleshy red portion is aromatic and the seeds have a white aril, creating an attractive contrast to seed dispersers (Fig. 1E and F), usually birds (Durigan et al. 2004, Gottsberger and Silberbauer-Gottsberger 2006).

\section{Phenological ObSERVATIONS}

We sampled and tagged all individuals of Xylopia aromatica with circunference at ground level $=3 \mathrm{~cm}$ inside 36 transects of $25 \times 2 \mathrm{~m}$, at least $50 \mathrm{~m}$ apart, equally distributed at the south and east faces of the fragment, with a total of 85 individuals, 35 at the south face and 50 at the east face. The phenological observations were carried out monthly on all marked individuals from January 2005 to December 2008, recording the presence or absence of flowering, separated in 
flower buds (Fig. 1A) and anthesis (Fig. 1B), and fruiting, separated into immature or unripe (Fig. 1C and D) and ripe fruits (Fig. 1E and F), according to Morellato et al. (2000).

\section{DATA ANALYSIS}

The phenological patterns were described based on the activity index, which indicates the percentage of individuals manifesting a phenophase at each observation date. To compare the percentage of individuals in each phenophase at the east and south faces we applied the nonparametric Wilcoxon Signed-Rank $(T)$ test (Zar 1999) for each year of observation. To check the influence of climate on the reproductive performance of individuals from the east and south faces, the spearman rank correlation test was estimated $\left(r_{s}\right)$ (Zar 1999) between the monthly activity indices and climate (temperature, rainfall and day length).

\section{SEASONALITY}

To check for the occurrence of seasonality in the reproductive phenological patterns, we applied circular statistics analyses as described in Morellato et al. (2000, 2010). There were three complete reproductive events during the four years of observations and for each event, the onset date of the first appearance of flower buds, flowers (anthesis), unripe and ripe fruits were estimated for each individual sampled at the east and south faces of the cerrado.

The test for the occurrence of a seasonal pattern has the null hypothesis of no seasonality or data are evenly distributed around the circle, and as an alternative the non-uniform, unimodal distribution and the existence of a significant mean angle or date (Morellato et al. 2000, 2010). We estimated: (i) the mean angle or onset date of each phenophase, and tested its significance using the Rayleigh test (Zar 1999) and (ii) the vector $r$, which is a measure of concentration around the mean angle. If the null hypothesis is rejected, the intensity of concentration around the mean angle $r$ can be considered a measure of the degree of seasonality (Morellato et al. 2000, 2010). The significant mean angles were compared using the Watson-Williams $(F)$ test (Zar 1999) to verify whether the average onset date differs between the east and south faces. The analyses followed Morellato et al. (2000, 2010) and were performed using the software ORIANA (Kovach 2010).

\section{SYNCHRONY}

To estimate the synchrony or the phenological overlap between pairs of individuals flowering/fruiting at the same face, for each phenological event we calculated the index of synchrony $(X i)$ from Augspurger (1983). To verify if there were differences in the synchrony of individuals between the east and south faces, we applied the nonparametric Mann-Whitney $(U)$ test (Zar 1999). We calculated the population index of synchrony $(Z)$ of Augspurger (1983) to determine the degree of synchrony among all individuals at each face, where $Z=0$ indicates no synchrony or overlap among individuals flowering/fruiting, and $Z=1$ indicates perfect or total synchrony of flowering/fruiting among all individuals at a given face in the same time of the year (Augspurger 1983, San Martin-Gajardo and Morellato 2003).

To understand the contribution of each individual in the phenological pattern at the east and south faces of the cerrado savanna studied, we determined, for each individual, over the four years of study, the predominant phenology pattern. We considered as presenting a continuous or episodic pattern individuals flowering or fruiting continuously over the year with interruptions of different duration, usually of one or two months, and/ or without a definite time of occurrence of flowering/ fruiting through the years. We considered as regular or seasonal individuals that flowering/fruiting once a year, at the same time over the years, with rare events taking place outside the main period of occurrence.

\section{RESULTS}

The phenological pattern at both faces was generally similar (Fig. 2B to E). Significant differences between the percentage of individuals reproducing at the east and south faces were observed for all phenophases in 2006, flower buds and anthesis in 2007, and flower buds and immature fruits in 2008, with higher medians at the east face (Table I).

\section{FLOWERING}

The production of flower buds was significantly seasonal, with the mean onset date in the beginning of the 

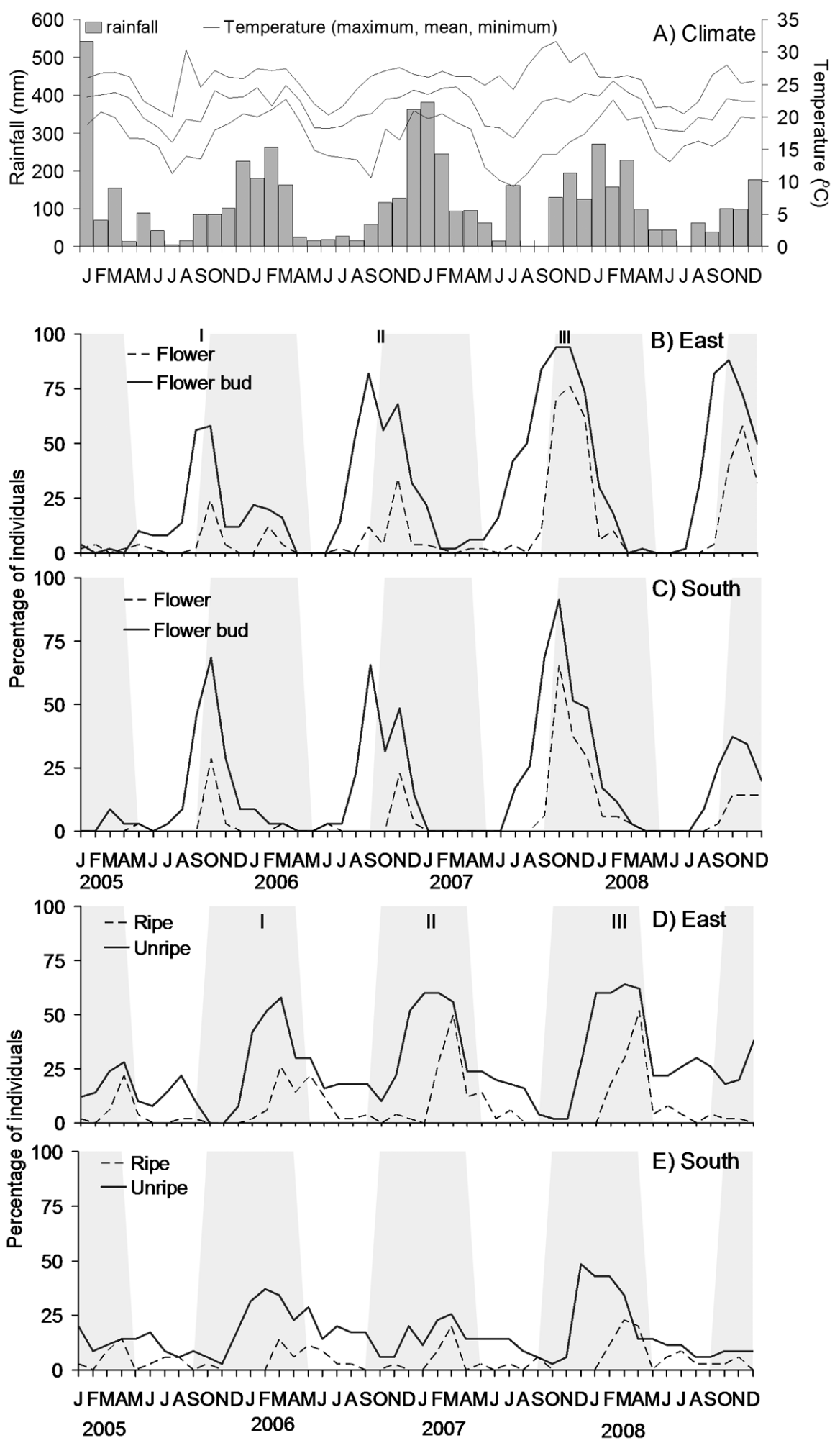

Fig. 2 - Climate of the study period and the reproductive phenology of Xylopia aromatica at east and south faces of a cerrado sensu stricto, Southeastern Brazil. Roman numerals (I, II e III) indicate the three reproductive events defined in the four years of study. The hatched area indicates the rainy season. 
TABLE I

Activity index medians of Xylopia aromatica at the east and south faces of a cerrado sensu stricto, Southeastern Brazil, and Wilcoxon Signed-Rank tests $(T)$ values for the comparison of activity indexes between faces. *Significant differences $(p<0.05)$.

\begin{tabular}{c|c|c|c|c|c|c}
\hline \multirow{2}{*}{ Years } & \multirow{2}{*}{ Phenophase } & \multicolumn{2}{|c|}{ Faces } & \multirow{2}{*}{$\mathrm{T}$} & \multirow{2}{*}{$\mathrm{Z}$} & \multirow{2}{*}{-level } \\
\cline { 2 - 7 } 2005 & East & South & & & \\
\hline \multirow{4}{*}{2006} & Flower bud & 9.00 & 5.71 & 25.00 & 0.25 & 0.80 \\
\cline { 2 - 7 } & Anthesis & 2.00 & 0.00 & 8.00 & 1.40 & 0.16 \\
\cline { 2 - 7 } & Unripe fruit & 11.00 & 10.00 & 26.00 & 0.62 & 0.53 \\
\cline { 2 - 7 } & Ripe fruit & 1.00 & 2.86 & 18.00 & 0.53 & 0.59 \\
\hline \multirow{4}{*}{2007} & Flower bud & 21.00 & 5.71 & 1.00 & 2.70 & $0.01^{*}$ \\
\cline { 2 - 7 } & Anthesis & 3.00 & 0.00 & 5.00 & 2.67 & $0.01^{*}$ \\
\cline { 2 - 7 } & Unripe fruit & 26.00 & 20.00 & 4.00 & 1.96 & $0.05^{*}$ \\
\cline { 2 - 7 } & Ripe fruit & 4.00 & 2.86 & 3.00 & 2.67 & $0.01^{*}$ \\
\cline { 2 - 7 } & Flower bud & 32.00 & 8.57 & 0.00 & 3.06 & $0.00^{*}$ \\
\cline { 2 - 7 } & Anthesis & 3.00 & 0.00 & 0.00 & 2.67 & $0.01^{*}$ \\
\cline { 2 - 7 } & Unripe fruit & 22.00 & 14.29 & 15.00 & 1.88 & 0.06 \\
\hline \multirow{4}{*}{2008} & Ripe fruit & 1.00 & 0.00 & 3.00 & 1.86 & 0.06 \\
\cline { 2 - 7 } & Flower bud & 24.00 & 10.00 & 3.00 & 2.50 & $0.01^{*}$ \\
\cline { 2 - 7 } & Anthesis & 2.00 & 2.86 & 3.00 & 1.86 & 0.06 \\
\hline & Unripe fruit & 28.00 & 11.43 & 0.00 & 3.06 & $0.00^{*}$ \\
\hline & Ripe fruit & 4.00 & 4.29 & 17.00 & 1.07 & 0.28 \\
\hline
\end{tabular}

dry season (Table II), differing between the east and south faces only in 2007 ( $F=15.25, p<0.01$, Table II). The peak of activity occurred in the transition between the dry and rainy seasons (Fig. 2B and C), with a significant positive correlation between flower buds and daylength at both faces $\left(r_{s}=0.38, p<0.01\right.$ and $r_{s}=0.39, p<0.01$ respectively for east and south faces).

Although flowering had started in the dry season, the highest activity of individuals was observed in the rainy season (Fig. 2B and C), with peaks coinciding with the first rains after a dry period. Flowering was observed almost throughout the period of study at the east face (Fig. 2B), while at the south face the intervals among events were longer, up to six months between 2006 and 2007 (Fig. 2C). The total duration of anthesis at the east face lasted approximately six months in the three events analyzed (Fig. 2B), while at the south face the entire duration of anthesis events varied from 2-7 months (Fig. 2C).

Individuals of $X$. aromatica at the east face presented a relative high flower bud synchrony, especially in the last two events, and low synchrony in two of the three events of anthesis. At the south face, individuals of $X$. aromatica showed low flowering synchrony, reaching a maximum of 0.45 in the third flower bud event (Table III). Individuals at the east face presents higher indices of synchrony than trees at the south face for all events considered, with significant differences for flower buds (second event) and anthesis (third event) (Table III).

\section{FRUITING}

Immature fruits showed a significant seasonal pattern, with the mean onset date between late November and early January, differing between the faces just regarding the mean onset date of the second event $(F=6.95, p=$ 0,01 , Table II). Immature fruits were observed throughout the study period, with an interval of two months in 2005 in the east face (Fig. 2D). The peaks of activity occurred in the wet season, usually between January and March (Fig. 2D), with significant positive correlations with temperature and rainfall at the east face $\left(r_{s}=0.40\right.$, $p<0.01$ and $r_{s}=0.30, p<0.05$ ). 


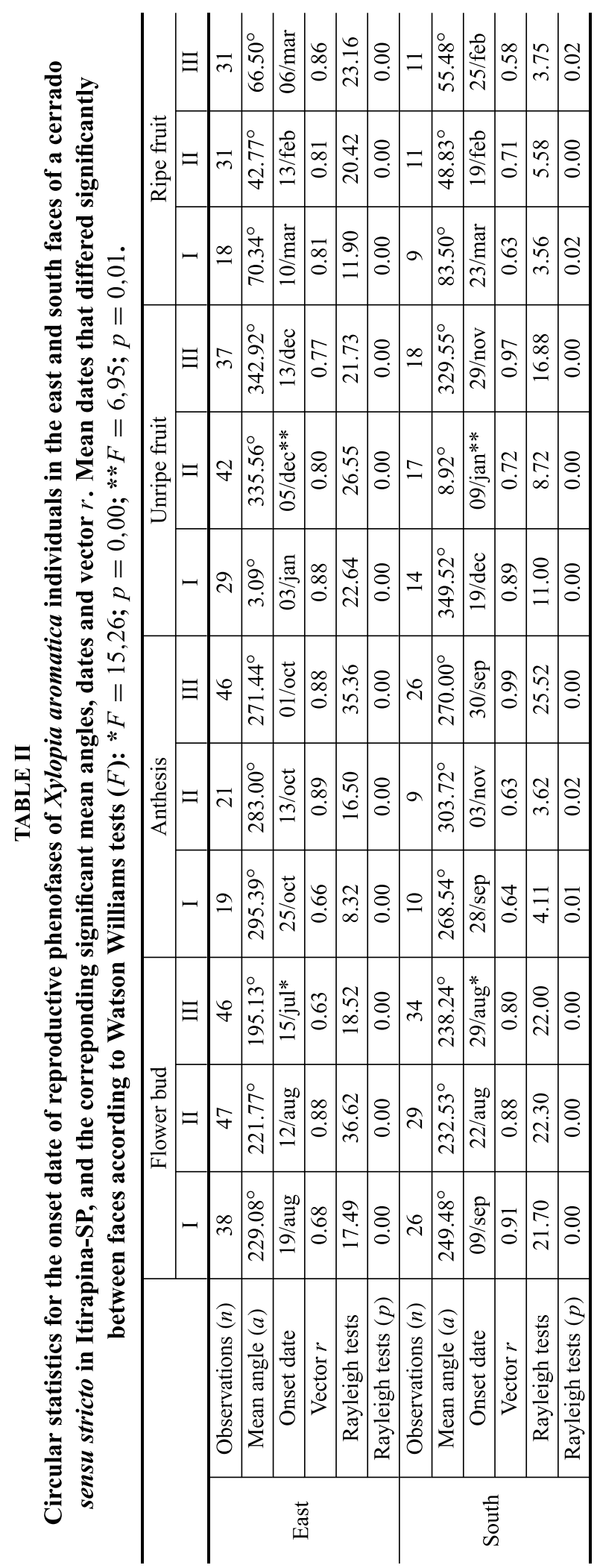


Fruit ripening was significantly seasonal, with the onset mean date late in the wet season in February and March (Table II). The onset dates did not differ between the east and south faces (Table II). The peaks of activity were observed between March and April (Fig. 2E), and there was a significant negative correlation between ripe fruit and daylength at the east and south faces $\left(r_{s}=\right.$ $-0.30, p<0.05$ and $r_{s}=-0.34, p<0.05$, respectively).

\section{TABLE III}

Index of synchrony $(Z)$ for reproductive phenofases of Xylopia aromatica individuals at the east and south faces of a cerrado sensu stricto, Southeastern Brazil, and Mann-Whitney tests $(U)$ for the individual synchrony $(X i)$ comparison between faces for the three complete reproductive events.

\begin{tabular}{c|c|c|c|c}
\hline \multirow{2}{*}{ Event } & \multirow{2}{*}{ Phenophase } & \multicolumn{2}{|c|}{$Z$} & \multirow{2}{*}{$U$} \\
\cline { 3 - 5 } & & East & South & \\
\hline \multirow{4}{*}{ I } & Flower bud & 0.42 & 0.35 & 731.0 \\
\cline { 2 - 5 } & Anthesis & 0.19 & 0.18 & 866.5 \\
\cline { 2 - 5 } & Unripe fruit & 0.41 & 0.17 & $593.0^{*}$ \\
\cline { 2 - 5 } & Ripe fruit & 0.18 & 0.06 & 729.0 \\
\hline \multirow{4}{*}{ II } & Flower bud & 0.63 & 0.32 & $520.0^{*}$ \\
\cline { 2 - 5 } & Anthesis & 0.26 & 0.13 & 762.0 \\
\cline { 2 - 5 } & Unripe fruit & 0.46 & 0.11 & $298.0^{*}$ \\
\cline { 2 - 5 } & Ripe fruit & 0.33 & 0.05 & $466.0^{*}$ \\
\hline \multirow{4}{*}{ III } & Flower bud & 0.75 & 0.45 & $547.5^{*}$ \\
\cline { 2 - 5 } & Anthesis & 0.65 & 0.33 & $610.0^{*}$ \\
\cline { 2 - 5 } & Unripe fruit & 0.49 & 0.26 & 781.0 \\
\cline { 2 - 5 } & Ripe fruit & 0.35 & 0.10 & $556.0^{*}$ \\
\hline \multicolumn{4}{|c}{$* p<0.05}$. & \multicolumn{3}{|c}{} \\
\hline
\end{tabular}

Individuals of $X$. aromatica at the east face presented low fruiting synchrony indices $(\mathrm{X})$ in all events, reaching a maximum of 0.49 for immature fruits and 0.35 for ripe fruits during the third event (Table III). At the south face trees were even less synchronous, with maximum values of $Z$ reaching 0.26 for immature and 0.10 for mature fruits (Table III). Individuals at the east face presented higher synchrony indices than trees at the south face for all events considered, with significant differences for the synchrony of immature fruits in the first event, for mature fruits (second event), and for immature and ripe fruits in the third event (Table III).

\section{Individual Reproductive PATterns}

Most individuals of $X$. aromatica at the east face presented a regular or seasonal flower bud (90\%) and anthesis $(62 \%)$ pattern, despite the episodic behavior of some individuals in the first two events of anthesis (Fig. $3 \mathrm{~A}$ and $\mathrm{C}$ ). At the south face, all individuals presented a regular flower bud pattern (Fig. 3B) and a continuous or episodic pattern (54\%) of anthesis (Fig. 3D).

The majority of individuals of $X$. aromatica at the east face presented a regular or seasonal pattern for immature $(52 \%)$ and mature $(67 \%)$ fruits, despite the continuous fruiting observed for some individuals in the first two events of immature fruits (Fig. $3 \mathrm{E}$ and G). At the south face, the individuals of $X$. aromatica showed an episodic or continuous pattern for immature fruits (64\%), and for ripe fruits half of the trees presented a regular and half an episodic pattern (Fig. 3F and H).

\section{DISCUSSION}

The individuals of Xylopia aromatica sampled at the east and south faces of the cerrado savanna showed seasonal annual phenological patterns, and started and peaked at the same time of year. Despite individual variations in the patterns over time and between faces, the seasonal pattern was confirmed for the four years of study at the east and south faces. The seasonal climate is regarded as the main factor defining the phenology patterns of cerrado savanna vegetation, leading to the recurrent reproductive seasonality found for many species of cerrado (Felfili et al. 1999, Batalha and Mantovani 2000, Oliveira and Gibbs 2000, Lenza and Klink 2006) which is considered an adaptive strategy of cerrado plants (Oliveira and Gibbs 2000, Oliveira 2008).

Despite the seasonal phenological pattern of $X$. aromatica observed in both cardinal orientations, differences were detected in the timing and duration of phenophases, and in the intervals between events and phenophases at the east and south faces of the cerrado studied. Xylopia aromatica is a species with a wide distribution, decreasing in abundance from open ("campo cerrado") to close ("cerradão") cerrado savanna physiognomies (Durigan et al. 2004), indicating a preference for lighter, dryer environments. Hereafter, the highest activity and synchrony displayed by individuals 


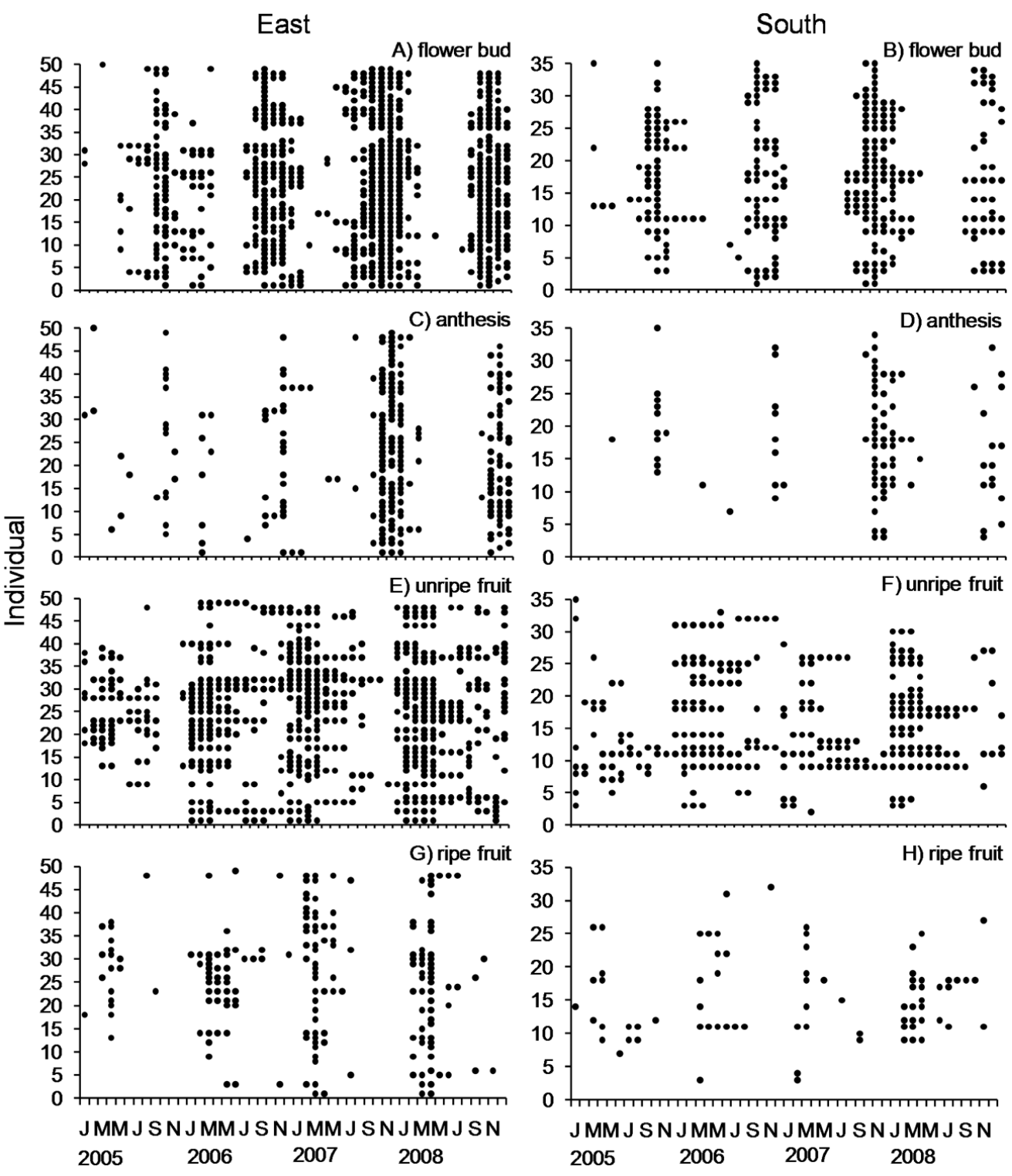

Fig. 3 - Reproductive phenological patterns of Xylopia aromatica individuals at the east $(n=50)$ and south $(n=35)$ faces of a cerrado sensu stricto, Southeastern Brazil.

sampled at the east face are related to the greater sunlight reaching the east cardinal position, associated with significant higher light incidence (PAR), temperature and canopy openness compared to the south face (P. Reys, unpublished data).

Additionally, the strong correlation observed between daylength and flower buds suggests daylength as the potential trigger for the onset of flower buds at the east face. Both increasing daylength and higher light incidence seem to affect flowering activity as a trigger and an environmental cue increasing reproductive activity. Wright and van Schaik (1994) highlight the importance of light in the tropics, and Rivera et al. (2002) suggest increasing day length as a cue for synchronous flowering at low latitudes. The relationship between increasing plant reproductive activity and high light incidence has been suggested by studies comparing flower production at different light conditions (e.g. Kapos et al. 1997, Landenberger and Ostergren 2002, Alberti and Morellato 2008). 
In the present study, $X$. aromatica started flowering at the end of the dry season, but the peak of anthesis activity was at the end of the dry season and early in the wet season, after the first rains that mark the transition between seasons. Therefore, $X$. aromatica can be included in the group of cerrado species presenting "early" or "precocious" flowering according to Oliveira (2008), with flowering occurring mainly at the beginning of the rainy season. The rainfall after a period of water stress (dry season) is considered one of the main cues inducing flowering in tropical forests (Opler et al. 1976, Morellato and Leitão-Filho 1990), a pattern also confirmed for three cerrado species of Kielmeyera in Central Brazil (Barros 2002), and Caryocar brasiliense in the cerrado of south Minas Gerais (Vilela et al. 2008).

The individuals of $X$. aromatica were fruiting mainly in the wet season, a pattern similar to that observed for animal-dispersed species trees in different phenological studies in the cerrado (Mantovani and Martins 1988, Batalha et al. 1997, Batalha and Mantovani 2000, Batalha and Martins 2004, Gottsberger and Silberbauer-Gottsberger 2006, Lenza and Klink 2006, Vilela et al. 2008). The largest amount of rainfall favors the growth and maturation of animal-dispersed fruits during the wet season, and ensure its availability and attractiveness to frugivorous and seed dispersers for a longer period of time (Mantovani and Martins 1988, Batalha et al. 1997, Batalha and Mantovani 2000, Batalha and Martins 2004, Gottsberger and SilberbauerGottsberger 2006).

Seasonality and synchrony were related to the relative contribution of each individual of $X$. aromatica to the phenology at both faces of cerrado. At the east face, the more synchronous flowering reflected the regular pattern of most individuals, especially for flower buds. Despite the low fruiting synchrony, most individuals presented a regular pattern in all events, which explains the seasonality observed at the east face. At the south face, the relationship between the synchrony and phenological pattern of individuals was detected for anthesis, immature and ripe fruits. The general episodic pattern determined a low or near zero synchronization index, i.e. asynchrony. On the other hand, for flower buds the predominance of individuals presenting a regular pattern did not lead to high synchrony, probably due to the long duration of this phenophase (Augspurger 1983, San Martin-Gajardo and Morellato 2003).

One possibility for these observed results is that the darker and more constant environment at the south face may reduce the influence of environmental factors synchronizing the time of occurrence of reproductive activity, especially light. A similar response is suggested by Koptur et al. (1988) for understory plant species of a tropical rainforest. Additionally, there may be more variation in the phenology of each individual when subjected to less favorable conditions for flowering or fruiting (Goulart et al. 2005). However, Lenza and Klink (2006) observed that, despite the variations in the phenology of each individual, the seasonal leafing and ripening pattern of 19 woody species of cerrado was maintained. Goulart et al. (2005) found few differences in the phenological pattern of populations of Plathymenia reticulada (Leguminosae - Mimosoideae) from cerrado, Atlantic forest and transition areas, and the differences were more associated with changes in the phenology of some individuals and the genetic variability of individuals of each population than to environmental differences.

The synchrony of flowering and fruiting within a population is usually associated with predator satiation and attractiveness to pollinators and seed dispersers in order to increase reproductive success (Bolmgren 1998). However, we must consider that the low synchrony can be compensated by large flowers or a bicolor display of mature fruits (Willson and Thompson 1982, Bolmgren 1998). Xylopia aromatica has large flowers (Fig. 1B) and ripe fruits with contrasting colors (Fig. 1E and F), which can facilitate their detection for pollinators and frugivores (Schaefer et al. 2006, Freitas and Bolmgren 2008, Cazetta et al. 2009), even when offered by a few isolated individuals. Moreover, the little synchrony may bring advantages in terms of escaping from predators and less competition for seed dispersers, leading to an increased plant reproductive success (Wheelwright 1985).

The variation of individual patterns within a population, for example, some few individuals presenting episodic or regular patterns but outside the period of peak activity of the cospecifics, may be important for maintaining the diversity of phenological patterns within the plant species and community. For instance, episodic 
events can occur during periods of resource scarcity for pollinators and dispersers, and contribute to the maintenance of wildlife, the plant-animal interactions and the genetic diversity of the populations, also revealing the phenotypic plasticity of the populations (Lenza and Klink 2006) which is fundamental to the species adaptability to environmental changes.

Therefore, the environmental conditions associated to the cardinal orientation of the face of the cerrado where each individual occurs affected the phenology of the individuals at each face and, as a result, the phenology of $X$. aromatica in the cerrado savanna area studied. Since $X$. aromatica presents a wide distribution and is adapted to diverse environmental conditions across the cerrado region (Almeida et al. 1998, Durigan et al. 2004), the observed differences were more subtle than initially expected. Studies involving more species and families with different pollination and seed dispersal modes may confirm the effects of local environmental conditions associated to cardinal orientation on the reproductive phenology of cerrado savanna trees, reinforcing the importance of considering the cardinal orientation in studies of edge effects and fragmentation.

\section{ACKNOWLEDGMENTS}

We thank the owners of Fazenda São José and IAB Instituto Arruda Botelho for allowing the conduct of the field work at the farm. The study was funded by the Fundação de Amparo à Pesquisa do Estado de São Paulo (FAPESP) (07/59779-6) and Conselho Nacional de Desenvolvimento Científico e Tecnológico (CNPq). MGGC received master scholarship from FAPESP (05/ 57740-0); RMS a undergraduate scientific scholarship from CNPq; PR a doctoral scholarship from the Coordenação de Aperfeiçoamento de Pessoal de Nível Superior (CAPES), and LPCM receives a Research Productivity fellowship and grant from CNPq. This work is a contribution from the Laboratory of Phenology and the Plant Phenology and Seed Dispersal Group.

\section{RESUMO}

O cerrado brasileiro vem sofrendo um processo intenso de fragmentação, que levou ao aumento de remanescentes sujeitos aos efeitos de borda e a alterações nas condições ambientais que podem afetar a fenologia das plantas. O objetivo deste trabalho foi verificar se a fenologia reprodutiva de Xylopia aromatica (Lam.) Mart. (Annonaceae) difere sob diferentes condições de luz em um cerrado sensu stricto no sudeste do Brasil. Comparamos a fenologia reprodutiva de árvores de $X$. aromatica distribuídas nas faces leste e sul do cerrado, observadas mensalmente de janeiro de 2005 a dezembro de 2008 . A face leste apresentou maior incidência de luz, temperaturas e aberturas do dossel em relação à face sul. X. aromatica apresentou reprodução sazonal em ambas as faces do cerrado, mas a porcentagem de indivíduos, sincronia e duração das fenofases foram maiores na face leste. $\mathrm{O}$ estudo demonstrou a influência das condições ambientais associadas à orientação cardeal das faces do cerrado no padrão fenológico de $X$. aromatica. Respostas similares poderão ser observadas em outras espécies de cerrado, afetando os padrões de visitação floral e produção de frutos, o que reforça a importância de considerarmos a orientação cardeal nos estudos de efeitos de borda e fragmentação.

Palavras-chave: cerrado, efeito de borda, fragmentação, fenologia reprodutiva, sincronia.

\section{REFERENCES}

Alberti LF AND Morellato LPC. 2008. Influência da abertura de trilhas antrópicas e clareiras naturais na fenologia reprodutiva de Gymnanthes concolor (Spreng.) Müll. Arg. (Euphorbiaceae). Rev Bras Bot 31: 53-59.

Almeida SP, ProençA CEB, SANo SM AND Ribeiro JF. 1998. Cerrado: espécies vegetais úteis. Planaltina: Embrapa, 464 p.

Augspurger CK. 1983. Phenology, flowering synchrony and fruit set of six neotropical shrubs. Biotropica 15: 257-267.

BARros MAG. 2002. Floração sincrônica e sistemas reprodutivos em quatro espécies de Kielmeyera Mart. (Guttiferae). Acta Bot Bras 16: 113-122.

Batalha MA, Aragaki S and Mantovani W. 1997. Variações fenológicas das espécies do cerrado em Emas (Pirassununga, SP). Acta Bot Bras 11: 61-78.

Batalha MA And Mantovani W. 2000. Reproductive phenological patterns of cerrado plant species at the Pé-de-Gigante Reserve (Santa Rita do Passa Quatro, SP, Brazil): a comparison between the herbaceous and woody floras. Rev Bras Biol 60: 129-145.

BAtAlha MA AND Martins FR. 2004. Reproductive phenology of the cerrado plant community in Emas National Park (central Brazil). Aust J Bot 52: 149-161. 
BOLMGREN K. 1998. The use of synchronization measures in studies of plant reproductive phenology. Oikos 82 : $411-415$.

Cazetta E, Schaefer HM and Galetti M. 2009. Why are fruits colorful? The relative importance of achromatic and chromatic contrasts for detection by birds. Evol Ecol 23: $233-244$.

Coutinho LM. 1978. O conceito de cerrado. Rev Bras Bot 1: $17-23$

Coutinho LM. 2006. O conceito de bioma. Acta Bot Bras 20: 13-23.

Durigan G, Baitelo JB, Franco GADC and SiqueiRA MF. 2004. Plantas do cerrado paulista: Imagens de uma paisagem ameaçada, Instituto Florestal, Secretaria do Meio Ambiente do Estado de São Paulo, São Paulo: Páginas e Letras Editora e Gráfica, 475 p.

DURIGAN G, SiQueIRA MF AND Franco GADC. 2007. Threats to the Cerrado remnants of the State of São Paulo, Brazil. Sci Agric 64: 366-363.

Felfili JM, Silva-Júnior MC, Dias BJ AND REZENDE AV. 1999. Estudo fenológico de Stryphnodendron adstringens (Mart.) Coville no cerrado sensu stricto da Fazenda Água Limpa no Distrito Federal, Brasil. Rev Bras Bot 22: 83-90.

FitTer AH AND FitTer RSR. 2002. Rapid Changes in Flowering Time in British Plants. Science 296: 16891691.

FREITAS L AND Bolmgren K. 2008. Synchrony is more than overlap: measuring phenological synchronization considering time length and intensity. Rev Bras Bot 31: 721-724.

FURLEY PA. 1999. The Nature and Diversity of Neotropical Savanna Vegetation with Particular Reference to the Brazilian cerrados. Global Ecol Biogeogr 8: 223-241.

GotTsberger G AND Silberbauer-Gottsberger I. 2006. Life in the Cerrado: A South American Tropical Seasonal Ecosystem, Pollination and Seed Dispersal, Ulm: Reta Verlag, 383 p.

Goulart MF, LEmos JP AND LOVATO MB. 2005. Phenological variation within and among populations of Plathymenia reticulata in Brazilian Cerrado, the Atlantic Forest and transitional sites. Ann Bot 96: 445-455.

Herrera CM. 1988. The Fruiting Ecology of Osyris quadripartita: Individual Variation and Evolutionary Potential. Ecology 69: 233-249.

Kapos V, Wandelli E, Camargo JL and Ganade G. 1997. Edge-related changes in environmental and plant responses due to forest fragmentation in Central Amazonia. In: LAURANCE WF AND BIERREGAARD RO (Eds), Tropical forest remnants, Chicago: Chicago University Press, p. 33-44.

KLink CA And Machado RB. 2005. Conservation of the Brazilian cerrado. Conserv Biol 19: 707-713.

Köeppen W. 1948. Climatologia, México: Fondo de Cultura Económica, $479 \mathrm{p}$.

Koptur S, Haber WA, Frankie GW and Baker HG. 1988. Phenological studies of shrub and treelet species in tropical cloud forests of Costa-Rica. J Trop Ecol 4: 323-346.

Kovach GLD. 2010. Oriana for Windows version 3.0 Kovach Computer Services, Wales: Pentraeth.

http://www.kovcomp.co.uk. Cited 10 January 2010.

Kronka ET AL. 1998. Áreas de Domínio do cerrado no Estado de São Paulo, São Paulo: Secretaria do Meio Ambiente, $84 \mathrm{p}$.

LANDENBERger RE AND OSTERGREN DA. 2002. Eupatorium rugosum (Asteraceae) flowering as an indicator of edge effect from clearcutting in mixedmesophytic forest. For Ecol Manage 155: 55-68.

LENZA E AND KLINK CA. 2006. Comportamento fenológico de espécies lenhosas em um cerrado sentido restrito de Brasília, DF. Rev Bras Bot 29: 627-638.

LORENZI R. 1992. Árvores brasileiras: manual de identificação e cultivo de plantas arbóreas nativas do Brasil. Nova Odessa: Plantarum, 384 p.

Mantovani W AND MaRTins FR. 1988. Variações fenológicas das espécies do cerrado da Reserva Biológica de Mogi-Guaçu, Estado de São Paulo. Rev Bras Bot 11: $101-112$

MARQUiS RJ. 1988. Phenological variation in the neotropical understory shrub Piper arielanum: causes and consequences. Ecology 69: 1552-1565.

Morellato LP AND LEITÃO-FILHO HF. 1990. Estratégias fenológicas de espécies arbóreas em floresta mesófila na Serra do Japi, Jundiaí, São Paulo. Rev Bras Biol 50: $163-$ 173.

Morellato LPC. 2004. Phenology, sex ratio, and spatial distribution among dioecious species of Trichilia (Meliaceae). Plant Biol 6: 491-497.

Morellato LPC, Alberti LF AND Hudson IL. 2010. Applications of circular statistics in plant phenology: a case studies approach. In: HUdSON IL AND KEATLEY M (Eds), Phenological Research: Methods for Environmental and Climate Change Analysis, Netherlands: Springer, p. $357-371$. 
Morellato LPC, Talora DC, Takahasi A, Bencke CC, Romera EC ANd Zipparro VB. 2000. Phenology of Atlantic rain forest trees: a comparative study. Biotropica 32: 811-823.

MURCIA C. 1995. Edge effects in fragmented forests: implications for conservation. Trends Ecol Evol 10: 58-62.

Newstrom LE, Frankie GW and Baker HG. 1994. A new classification for plant phenology based on flowering patterns in lowland tropical forest trees at La Selva, Costa Rica. Biotropica 26: 141-159.

OliveIRA MIB AND SigRIST MR. 2008. Fenologia reprodutiva, polinização e reprodução de Dipteryx alata Vogel (Leguminosae-Papilionoideae) em Mato Grosso do Sul, Brasil. Rev Bras Bot 31: 195-207.

OLIVEIRA PE. 2008. Fenologia e biologia reprodutiva das espécies de cerrado. In: SANO SM, ALMEIDA SP AND RIBEIRO JF (Eds), Cerrado: ecologia e flora, Brasília: Embrapa, p. 273-290.

OliveIRA PE AND GIBBS PE. 2000. Reproductive biology of woody plants in a cerrado community of Central Brazil. Flora 195: 311-329.

Opler PA, Frankie GW ANd BAKer HG. 1976. Rainfall as a factor in the release, timing, and synchronization of anthesis by tropical trees and shrubs. J Biogeogr 3: 231-236.

Pivello VR, Shida CN ANd Meirelles ST. 1999. Alien grasses in Brazilian savannas: a threat to the biodiversity. Biodivers Conserv 8: 1281-1294.

Restrepo C, Gomez N And Heredia S. 1999. Anthropogenic edges, treefall gaps, and fruit-frugivore interactions in a Neotropical Montane Forest. Ecology 80: 668-685.

Rivera G, Elliott S, Caldas LS, Nicolossi G, CORADIN VTR AND BORCHERT R. 2002. Increasing day length induces spring flushing of tropical dry forest trees in the absence of rain. Trees Struct Funct 16: 445-456.

SAN Martin-Gajardo I AND Morellato LPC. 2003 Inter and intraspecific variation on reproductive phenology of the Brazilian Atlantic forest Rubiaceae: ecology and phylogenetic constraints. Rev Biol Trop 51: 691698.
SChaefer HM, LEVEy DJ, Schaefer V AND AVERY ML. 2006. The role of chromatic and achromatic signals for fruit detection by birds. Behav Ecol 17: 784-789.

SCHWARTZ MD. 2003. Phenology: an integrative environmental science, Dordrecht: Kluwer Academic Publishers, $592 \mathrm{p}$.

SilVA JF, FARIÑAS MR, FELFILI JM AND KLINK CA. 2006. Spatial heterogeneity, land use and conservation in the cerrado region of Brazil. J Biogeogr 33: 236-548.

TURTON SM AND Freiburger HJ. 1997. Edge and aspect effects in the microclimate of a small Tropical Forest remnant on the Atherton Tableland, Northeastern Australia. In: LAURANCE WF AND BIERREGAARD RO (Eds), Tropical forest remnants, Chicago: Chicago University Press, p. 33-44.

Vilela GF, CARvalho D ANd Vieira FA. 2008. Fenologia de Caryocar brasiliense Camb. (Caryocariaceae) no Alto Rio Grande, sul de Minas Gerais. Cerne 14: 317-329.

WALES BA. 1972. Vegetation analysis of north and south edges in a mature oak-hickory forest. Ecol Monogr 42: 451-471.

WhEELWRIGHT NT. 1985. Competition for dispersers, and the timing of flowering and fruiting in a guild of tropical trees. Oikos 44: 465-477.

Willson MF AND ThOMPSON JN. 1982. Phenology and ecology of color in bird-dispersed fruits, or why some fruits are red when they are "green". Can J Bot 60: 701713.

Wright SJ AND VAN SCHAIK CP. 1994. Light and the phenology of tropical trees. Am Nat 143: 192-199.

ZAR HJ. 1999. Biostatistical analysis, New Jersey: PrenticeHall, 663 p. 